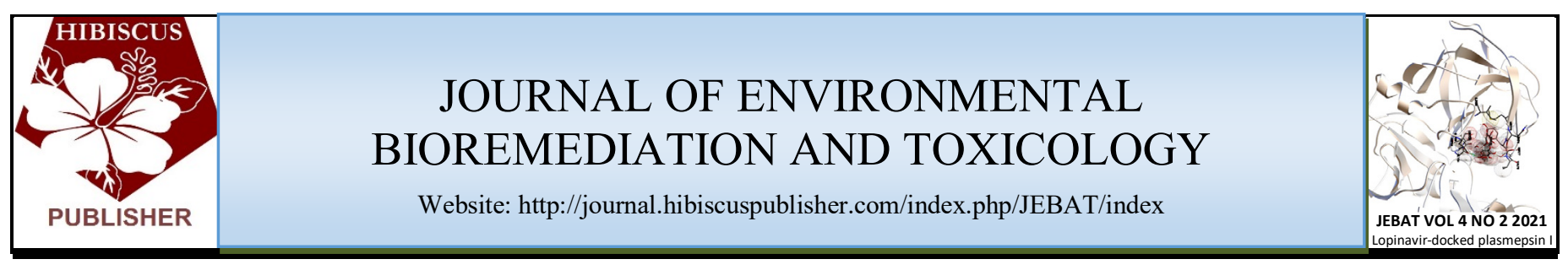

\title{
Inhibitory Effect of Sodium Citrate, Sodium Nitrite and Cinnamaldehyde on Biofilm-forming Escherichia coli 0157:H7
}

\author{
Jauro, A.H. ${ }^{1}$, Shu'aibu, I. ${ }^{1}$, Lawan, G. ${ }^{1}$,Adamu, M.T. ${ }^{1}$, Iliyasu, M.Y. ${ }^{2}$ and A.F. $\operatorname{Umar}^{2}$ \\ ${ }^{1}$ Department of Microbiology, Faculty of Science, Gombe State University (GSU), P.M.B 127, Gombe, \\ Gombe state, Nigeria. \\ ${ }^{2}$ Department of Microbiology, Abubakar Tafawa Balewa University (ATBU) P.M. B. 0248, \\ Bauchi, Nigeria. \\ *Corresponding author: \\ Dr. A.H. Jauro, \\ Department of Microbiology, \\ Faculty of Science, \\ Gombe State University, \\ P.M.B 127, Gombe, \\ Gombe state, \\ Nigeria \\ Email: hahadiza@gsu.edu.ng
}

\begin{tabular}{l}
\hline HISTORY \\
Received: $23^{\text {rd }}$ Aug 2021 \\
Received in revised form: $24^{\text {th }}$ Oct 2021 \\
Accepted: $12^{\text {th }}$ Nov 2021 \\
\hline KEYWORDS \\
Food additives \\
Inhibitory effect \\
Antibiofilm \\
Cinnamaldehyde \\
E. coli 0157:H7
\end{tabular}

\begin{abstract}
The development of biofilms by the foodborne pathogens attached to surfaces in the food processing environments results in the deterioration of products, persistence of pathogenic bacteria and transmission of food-associated diseases. In addition, biofilms are more resistant to antimicrobials than their planktonic counterparts which make their elimination from food and the food processing facilities a great challenge. This study aim was to determine the inhibitory effect of food additives on biofilm forming Escherichia coli O157:H7. The isolate obtained was subjected to Gram's staining and various biochemical identifications and later confirmed by latex agglutination test. Biofilm formation potential was done on Congo red media and the confirmed biofilm former was subjected to biofilm formation at $10^{\circ} \mathrm{C}$ and $37^{\circ} \mathrm{C}$ for $168 \mathrm{hrs}$. Antimicrobial susceptibility testing, MIC, MBC, and antibiofilm effect was determined following CLSI 2017 guideline. The highest zone of growth inhibition of $31 \mathrm{~mm}$ was exhibited by cinnamaldehyde, sodium nitrite with $26 \mathrm{~mm}$ and sodium citrate with $13 \mathrm{~mm}$. The MIC $2.5 \mathrm{mg} / \mathrm{mL}$ was recorded for sodium citrate, $0.25 \mathrm{mg} / \mathrm{mL}$ for sodium nitrite and $0.125 \mu \mathrm{l} / \mathrm{mL}$ for cinnamaldehyde. Strong biofilm was formed at $37^{\circ} \mathrm{C}$ with $7.82 \times 10^{9} \mathrm{CFU} / \mathrm{mL}$ viable cells at $168 \mathrm{hrs}$ while $6.79 \times 10^{9}$ $\mathrm{CFU} / \mathrm{mL}$ were obtained at $10^{\circ} \mathrm{C}$. All the three additives showed antibiofilm effect (at $10^{\circ} \mathrm{C}$ and $37^{\circ} \mathrm{C}$ ), cinnamaldehyde exhibited $70 \%-90.1 \%$, sodium nitrite; $70 \%-88.2 \%$ inhibition and sodium nitrite; $75 \%-88 \%$ inhibition respectively. This study showed that sodium citrate, sodium nitrite and cinnamaldehyde exerted strong antimicrobial and antibiofilm properties indicating their potential as good preservatives.
\end{abstract}

\section{INTRODUCTION}

Food safety is a major concern of every sector of the food industry. Survival of E. coli O157:H7 with biofilm forming potential (BFP) in commercial food premises is a possible danger to the health of consumers especially in societies where most of the population depend on it for their daily meals. The development of biofilms by the foodborne pathogens attached to surfaces in the food processing environments results in the deterioration of products, persistence of pathogenic bacteria and transmission of food-associated diseases [1]. In addition, bacteria in biofilms are more resistant to antimicrobials than their planktonic counterparts which make their elimination from food and the food processing facilities a great challenge. Therefore, their presence creates a great and urgent concern for the current food industries (small- and large-scale industries) and public health [2]. Food contamination otherwise called foodborne infection (FBDs) or foodborne sickness (FBIs) happens because of ingestion of food or water with pathogenic microorganisms like microbes, growths, infections or parasites, the synthetic substances they delivered just as poisons which might be of biochemical or compound nature [3]. The primary driver of FBIs incorporates microorganisms $(66 \%)$, parasite $(4 \%)$ infections $(4 \%)$ and synthetics $(26 \%)$. The bacterial microorganisms that cause FBDs have diverse harmfulness factors such poison creation (in food or intestinal system) which present them the 
capacity to cause infection. Utilization of food tainted with foodborne microorganisms and microbial side-effects, for example, poisons could bring about genuine sicknesses and monetary loses [4]. Presently, multiple million passings happen each year in emerging nations due to foodborne infections, which are among in excess of 13 zoonoses embroiled in more than 2 billion diseases around the world [5].

World Health Organization (WHO) set up the Foodborne Disease Burden Epidemiology Reference Group (FERG) which assessed those 31 foodborne sicknesses came about in more than 600 million ailments and 420,000 passing's worldwide in 2010 [6]. Food-borne diseases have an effect in both creating and created nations with the vast majority of the critical extent of instances of diarrhoeal being foodborne in beginning [7]. A few instances of foodborne infections which have prompted mortality and hospitalization were accounted for in Nigeria despite the fact that it has no authority foodborne sickness reconnaissance framework. Nigeria is a country with more than 170 million individuals. In any case, it was accounted for that main about couple of instances of foodborne sicknesses that happen every year [8]. WHO has revealed an expected instance of 200,000 passings from food contamination through utilization of food tainted with pathogenic microorganisms particularly E. coli and Salmonella because of inappropriate handling and safeguarding and 20,000 passings from food pesticides openness [9].

Escherichia coli $0157: \mathrm{H} 7$ serotype; designated by its somatic $(\mathrm{O})$ and flagellar $(\mathrm{H})$ antigens, produces either or both of two phage-encoded toxins E. coli $\mathrm{O} 157: \mathrm{H} 7$ is an important serotype strain of characterised by the production of more than one type of cyto-toxin collectively known as shiga-like toxin (SLT) that causes diarrhoea in human and animals when consumed in contaminated food or water [1] In most cases cattle's are the main reservoirs of $E$. coli $\mathrm{O} 157: \mathrm{H} 7$, it is an inhabitant of gastrointestinal tract of ruminant. Source of infection is contamination of food by human and animal faeces. The pathogenicity of STEC is determined by several virulence factors that are encoded by chromosomal pathogenicity islands, phage chromosomes integrated in the bacterial genome as well as plasmids. Shiga toxins are members of a toxin family that share many common features [10]. In Europe, 14,000 cases in over 24 countries have occurred from 2000 to 2005 , of which $62 \%$ belong to the $\mathrm{O} 157$ serogroup [11]. A review of 90 outbreaks in Britain, Ireland, Scandinavia, Canada, USA and Japan indicated that about $20 \%$ of outbreak cases resulted from secondary spread [12].

Escherichia coli O157:H7 serotype; designated by its somatic $(\mathrm{O})$ and flesignat $(\mathrm{H})$ antigens, delivers either or both of two phage-encoded poisons E. coli $\mathrm{O} 157: \mathrm{H} 7$ is a significant serotype strain of described by the creation of more than one sort of cyto-poison all in all known as shiga-like poison (SLT) that causes the runs in human and creatures when burned-through in debased food or water [1]. Dairy cattle's are the fundamental repositories of E. coli $\mathrm{O} 157: \mathrm{H7}$, it is an occupant of gastrointestinal lot of ruminant. Wellspring of disease is tainting of food by human and creature dung. The pathogenicity of STEC is dictated by a few harmfulness factors that are encoded by chromosomal pathogenicity islands, phage chromosomes coordinated in the bacterial genome just as plasmids. Shiga poisons are individuals from a poison family that share numerous normal elements [10]. In Europe, 14,000 cases in more than 24 nations have happened from 2000 to 2005 , of which $62 \%$ have a place with the O157 serogroup [11]. An audit of 90 episodes in England, Ireland, Scandinavia, Canada, USA and Japan demonstrated that around $20 \%$ of flare-up cases came about because of auxiliary spread (Snedeker et al., 2009).

Microorganisms can develop on biotic and abiotic surface and structure biofilm; a complex organized multicellular network of cells clung to a surface or an interface, which are implanted in a self-created extracellular polymeric substance (EPS) [12]. Biofilm is made out of $90 \%$ network, which is comprised of water for ingestion of supplement, metabolites and lysing of cell item and $10 \%$ microorganism. The EPS contains proteins, polysaccharides, DNA, RNA (for foundation of design), peptidoglycan, lipids and phospholipids [13]. Biofilm development happens when microorganisms joined to a surface and develops with consistent colonization and spread over the surface. The arrangement is affected by certain variables related with the nature and particularity of the strains of bacterium. In this manner, making its creation a significant component for microbes [12]. Reports of some exploration have shown that biofilm can be found in lowered and moist condition; drifting mat, fluid surface, strong surface, normal oceanic frameworks, living tissues, clinical gadgets for example catheters and modern funneling frameworks $[14,15]$

The objective of food handling is to give safe items great organoleptic attributes. This is accomplished using different scope of food added substances or additives to improve and keep up with the food quality (healthy benefit, surface, security, taste and presence of the food) and wellbeing, accordingly, broadening the time span of usability of food items. Thusly disposal of biofilms or minimization of biofilms framed by foodborne microbes utilizing the food added substances is essential to give protected and great quality items to shoppers, and this thus legitimizes the requirement for this review. Protection of new food quality being of most extreme significance, new inventive method for hindering pathogenic microorganisms in food sources are being assessed to be compelling at obliterating microorganisms and safeguard the physical and organoleptic properties.

\section{MATERIALS AND METHOD}

\section{Confirmation of Bacterial Isolate}

The bacterial isolate (E. coli $\mathrm{O} 157: \mathrm{H} 7)$ was confirmed through Gram's staining and various biochemical identifications (IMViC) and later confirmed by latex agglutination test $[10,14]$

\section{Biofilm Formations Potential (BFP) Assays}

\section{Biofilm Formation Using Congo Red Agar (CRA)}

The confirmed E. coli $\mathrm{O} 157: \mathrm{H} 7$ was further subjected to biofilm production assay to determine the phenotypic expression of colonies in Congo Red Agar (CRA) medium. Briefly, the Congo Red Agar was prepared by dissolving $37 \mathrm{~g}$ Brain Heart Infusion (BHI) agar (TITAN BIOTECH LTD), 36g sucrose and $0.8 \mathrm{~g}$ congo red (BDH LTD) in 1 litre. The solution was sterilized by autoclaving at $121^{\circ} \mathrm{C}$ for $15 \mathrm{~min}$. After inoculation, the plates were incubated for $18 \mathrm{~h}$ at $37^{\circ} \mathrm{C}$ were the biofilm-producing isolates originate as black colonies $[15,16]$

\section{Biofilm Formation Using Tissue Culture Plate (TCP)}

The method of $[16,17,18]$ was employed for biofilm formation. The strain of E. coli $\mathrm{O} 157: \mathrm{H} 7$ was subcultured into $6 \mathrm{~mL}$ of Tryptone Soya Broth (TSB) (TITAN BIOTECH LTD) and subjected to incubation at $37^{\circ} \mathrm{C}$ for $16-24 \mathrm{~h}$. After incubation, $5 \mathrm{~mL}$ of the incubated strain was centrifuged at $5000 \mathrm{x}$ g for $5 \mathrm{~min}$ and washed twice in $5 \mathrm{~mL}$ of Phosphate Buffer Saline (PBS). The cell pellets were re-suspended in $10 \mathrm{~mL}$ of TSB at an optical 
density of 0.5 at $600 \mathrm{~nm}$ (OD600) which corresponds to approximately $10^{8} \mathrm{CFU} / \mathrm{mL}[18]$.

Biofilm formation on TCP was carried out by pipetting 200 $\mu \mathrm{l}$ aliquot of $10^{8} \mathrm{CFU} / \mathrm{mL}$ suspension of the test organism into sterile 96-wells of TC plates while control wells filled with broth only and incubate at $10^{\circ} \mathrm{C}$ and $37^{\circ} \mathrm{C}$ for $24,48,72$ and $168 \mathrm{~h}$ in order for the bacteria to attach to the pirates of the wells. Following the attachment step, the planktonic bacteria were removed by pipetting. After the removal of loosely attached cells, the wells were renewed with $200 \mu \mathrm{l}$ of TSB every $24 \mathrm{~h}$ up to the $7^{\text {th }}$ day $(168 \mathrm{~h})$ to allow for bacterial growth and biofilm development.

\section{Enumeration of Biofilm cells}

Biofilm cells formed on TCP at 24, 48, 72, 96, 120, 144 and 168 $\mathrm{h}$ were enumerated by vortexing method as described by [12]. After incubation, the wells were washed 3 times with $10 \mathrm{~mL}$ phosphate buffer saline PBS (pH 7.4 \pm 0.1 ) with shaking in order to remove the loosely attached cells; it was then vortexed for 2 min at maximum speed to detach biofilm cells. Detached cells were enumerated by agar plating.

\section{Determination Of Biofilm Inhibition}

\section{Inoculum Preparation}

The inocula of the strong biofilm forming strains was prepared and subcultures on TSA which was incubated at $37^{\circ} \mathrm{C}$ for $24 \mathrm{~h}$. Colonies of each isolate were then transferred into TSB using sterile cotton swab to match the turbidity standard of 0.5 McFarland $\left(15 \times 10^{8} \mathrm{CFU} / \mathrm{mL}\right)$

\section{Preparation of Concentrations of Food Additives for Use as} Antimicrobial Agent

The food additives (sodium citrate, sodium nitrite and cinnamic aldehyde) were purchased and prepared in solutions. The solution was then diluted to different concentrations based on the application amount for food preservation $(2 \%, 1 \%, 0.5 \%, 0.25 \%$ and $0.125 \%$ ) with appropriate solvent [19]

\section{In-vitro Antimicrobial Activity of Food Additives on E. coli 0157:H7 Isolate}

In-vitro antimicrobial activity of food additives was conducted against isolated E. coli $\mathrm{O} 157: \mathrm{H7}$, using the agar well diffusion method as described by Clinical and Laboratory Standards Institute [20]. The standardized isolate was streaked over the entire surface of Mueller Hinton agar plates with a sterile cotton swab. Then, a hole with a diameter of 6 is punched aseptically with a sterile cork borer, and a volume of $100 \mu \mathrm{l}$ of different concentrations of food additives (Sodium citrate, Sodium nitrite, Cinnamic aldehyde) was introduced into the well, Augmentine disc $30 \mu \mathrm{g}$ (Oxoid) was used as positive control in the assay. The plates were then incubated at $37^{\circ} \mathrm{C}$ for $24 \mathrm{~h}$. The size of the clear zone was measured in $\mathrm{mm}$. This was done in triplicates.

\section{Determination Minimum Inhibitory Concentrations (MIC)} and Minimum Bactericidal Concentrations (MBC)

The MIC and MBC determination was performed in accordance with the recommendation of [21]. These were performed in a 96well microtiter plate using two-fold microbroth dilution technique using an inoculum that matched with McFarland's turbidity standard $\left(1.5 \times 10^{8} \mathrm{CFU} / \mathrm{mL}\right)$. The MIC is defined as the lowest concentration of the food additive that completely inhibit visible growth. The MBC was determined by subculturing unto MHA plate the wells that showed no visible growth for the MIC.

\section{Inhibitory effect of food additives on Biofilm formation}

The method of $[22,23]$ was employed to determine the inhibitory effect of food additives on biofilm. Two-fold dilutions were made to achieve a concentration range of 0.625 to $5 \mu \mathrm{l} / \mathrm{mL}$ for cinnamic aldehyde, 2.5 to $160 \mathrm{mg} / \mathrm{mL}$ for sodium citrate and 0.625 to $2 \mathrm{mg} / \mathrm{mL}$ for sodium nitrite. Aliquots of $100 \mu \mathrm{L}$ of double-strength Mueller-Hinton broth was added to the 96-well microtitre plate and the additives were added. Ten microliters of microorganisms $(24 \mathrm{~h}$ broth culture diluted to $0.5 \mathrm{McF}$ arland standard) was added, and then incubated at $37^{\circ} \mathrm{C}$ for $24,48,72$, $96,120,144$ and $168 \mathrm{~h}$. After incubation, planktonic cells were aspirated, and the wells washed and the absorbance was read at $600 \mathrm{~nm}$ to determine the optical density (OD). The percentage of biofilm inhibition was determined by subtracting the optical density of treated plate from the optical density of control media. This procedure was carried out in triplicate.

$$
\% \text { Biofilm inhibition }=\frac{\text { Optical density }(\mathrm{OD}) \text { of control }- \text { OD of treatment } \quad \times 100}{\text { Optical density of control }}
$$

\section{Statistical Analysis}

The results were expressed as mean $\pm \mathrm{SD}$, two-way ANOVA test was used to compare results among and within groups for any significant difference in efficacy of food additives against biofilm forming $E$. coli $\mathrm{O} 157: \mathrm{H} 7 \mathrm{using}$ SPSS version 2.5

\section{RESULTS AND DISCUSSION}

\section{Biofilm formation of $E$. coli $\mathrm{O} 157: \mathrm{H} 7$ at varying temperature} of $10{ }^{\circ} \mathrm{C}$ and $37^{\circ} \mathrm{C}$

E. coli $\mathrm{O} 157: \mathrm{H} 7$ which commonly contaminates food and contact surfaces in food industries can develop biofilm. This study has shown (Fig. 1) that E. coli O157:H7 can form biofilm at varying temperature of $10^{\circ} \mathrm{C}$ and $37^{\circ} \mathrm{C}$ (minimum and optimum) of bacterial growth for $7168 \mathrm{~h}$.

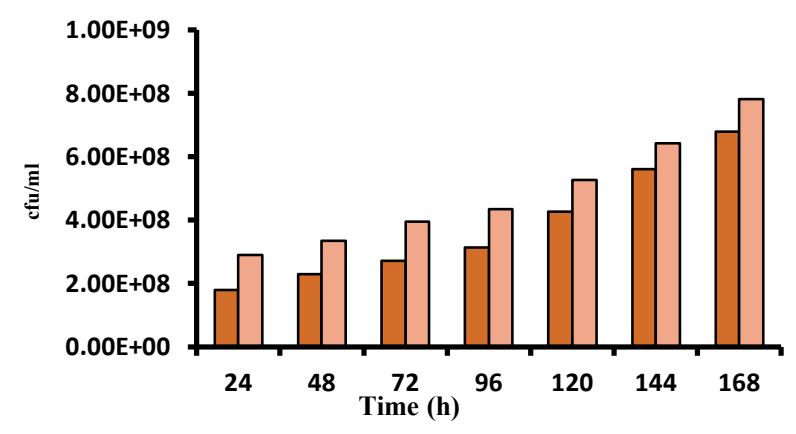

Fig. 1. Enumeration of $E$. coli $\mathrm{O} 157: \mathrm{H} 7$ Biofilm cells at $10^{\circ} \mathrm{C}$ and $37^{\circ} \mathrm{C}$.

The biofilm cells enumerated after $24 \mathrm{~h}$ of incubation at $37{ }^{\circ} \mathrm{C}$ and $10^{\circ} \mathrm{C}$ was $3.9 \times 10^{8} \pm 0.01 \mathrm{CFU} / \mathrm{mL}$ and $1.81 \times 10^{8} \pm 0.01$ $\mathrm{CFU} / \mathrm{mL}$ respectively. After $48 \mathrm{~h}$ of incubation, number of cells enumerated increase to $6.34 \times 10^{8} \pm 0.02 \mathrm{CFU} / \mathrm{mL}$ and $2.30 \times 10^{8}$ $\pm 0.01 \mathrm{CFU} / \mathrm{mL}$ at $37{ }^{\circ} \mathrm{C}$ and $10{ }^{\circ} \mathrm{C}$, respectively. Variation and increase in biofilm cell density is due increase in incubation time and temperature. At $168 \mathrm{~h}$, the cells enumerated reached $7.80 \times 10^{9}$ $\pm 0.02 \mathrm{CFU} / \mathrm{mL}$ and $6.79 \times 10^{8} \pm 0.04 \mathrm{CFU} / \mathrm{mL} 37^{\circ} \mathrm{C}$ and $10^{\circ} \mathrm{C}$ respectively. There is a significant difference $(\mathrm{P}<0.05)$ at $95 \%$ confidence interval within and between group when compared. The increase in biofilm formation with increase in temperature and time in this study is in line with the work of [21] who also reported higher increase in biofilm cells formation on wood and glass at varying temperature. 
The higher increase in biofilm cells reported by [21] may be due to variation of surface and composition of the material foe bacterial adhesion. The higher increase in E. coli $\mathrm{O} 157: \mathrm{H} 7$ biofilm development in this study is also in line with the work of [18] who also reported an increase in E. coli O157:H7 cells developed in tissue culture plate at $37^{\circ} \mathrm{C}$.

\section{In-vitro Antimicrobial Activity of Food Additives on E. coli O157:H7 Isolate}

In vitro antimicrobial effects of food preservatives have been clearly elucidating the susceptibility or how resistance an organism is to it.

Table 1. Antimicrobial susceptibility pattern showing mean zone of growth inhibition $(\mathrm{mm}) \pm \mathrm{SEM}$ of food additives against $E$. coli O157:H7

\begin{tabular}{lrrrrr}
\hline Food additives & & \multicolumn{4}{c}{ Concentrations $(\mathrm{mg} / \mathrm{mL})$} \\
& $2 \%$ & $1 \%$ & $0.5 \%$ & $0.25 \%$ & Control
\end{tabular}

\begin{tabular}{llllll}
\hline Sodium citrate & $13.00 \pm 1.15$ & $10.00 \pm 0.58$ & $9.00 \pm 0.58$ & $7.67 \pm 0.33$ & $24.6 \pm 0.85$
\end{tabular} $\begin{array}{llllll}\text { Sodium Nitrite } & 26.00 \pm 0.58 & 20.33 \pm 0.88 & 14.67 \pm 0.67 & 10.33 \pm 0.88 & 24.8 \pm 0.52\end{array}$ $\begin{array}{llllll}\text { Cinnamaldehyde } & 31.67 \pm 0.88 & 27.33 \pm 0.33 & 25.33 \pm 0.33 & 17.67 \pm 0.88 & 25.6 \pm 0.89\end{array}$ Zones of growth inhibition $=$ diameter of well plus zones of growth inhibition; diameter of well $=6 \mathrm{~mm}$. the mean zone of

Note; growth inhibition was determined from three independent results $(n)=3$; SEM $=$ standard error mean

In this study, the antimicrobial susceptibility pattern of sodium citrate, sodium nitrite and cinnamaldehyde showed (table 1) high zone of inhibition $(\mathrm{mm})$ of $13.00 \pm 0.88,26.00 \pm 0.58$ and $31.67 \pm 0.88$ respectively at $2 \%$ concentration each. The least zone of inhibition recorded for each additive was $0.25 \%$ concentration where sodium citrate had $7.67 \pm 0.33 \mathrm{~mm}$, sodium nitrite; $10.33 \pm 0.88 \mathrm{~mm}$ and cinnamaldehyde $17.67 \pm 0.88 \mathrm{~mm}$. Among the three additives used, cinnamaldehyde has the highest zone of inhibition $(31.67 \pm 0.88) \mathrm{mm}$ while sodium citrate showed the least zone of inhibition $(7.67 \pm 0.33) \mathrm{mm}$ thus, showing that cinnamaldehyde has strong antimicrobial effect against $E$. coli O157:H7.

This finding is in line with a previous work who reported antimicrobial susceptibility of cinnamaldehyde against avian $E$. coli inhibition zones diameters ranging from 16 to $44 \mathrm{~mm}$. Similarly, report made by [15] on microbiological profiling of food additives and evaluation of their antibacterial efficacy showed a clear zone of inhibition of $8-22 \mathrm{~mm}$ measured on agar well diffusion.

Table 2. Minimum inhibitory concentration (MIC) and minimum bactericidal concentration (MBC) of food additives against E. coli O157:H7.

\begin{tabular}{|c|c|c|c|c|c|c|c|c|}
\hline & & & centra & tions & & & MIC & $\mathrm{MBC}$ \\
\hline Food additives & 0 & 0.625 & 1.25 & 2.5 & 5 & 10 & & \\
\hline Sodium citrate & + & + & + & - & - & - & $2.5 \mathrm{mg} / \mathrm{mL}$ & $5 \mathrm{mg} / \mathrm{mL}$ \\
\hline Sodium nitrite & + & + & + & - & - & - & $0.25 \mathrm{mg} / \mathrm{mL}$ & $1 \mathrm{mg} / \mathrm{mL}$ \\
\hline Cinnamaldehyde & + & + & - & - & - & - & $0.125 \mu \mathrm{l} / \mathrm{mL}$ & $0.25 \mu \mathrm{l} / \mathrm{mL}$ \\
\hline
\end{tabular}

In this study, the MIC and MBC of sodium citrate, sodium nitrite and cinnamaldehyde recorded showed (Table 2) that all the three additives have varying MIC and MBC that can inhibit and cause lethal effect on biofilm forming E. coli $\mathrm{O} 157: \mathrm{H} 7$.
The result showed that sodium citrate had MIC at 2.5 $\mathrm{mg} / \mathrm{mL}$ and $\mathrm{MBC}$ at $5 \mathrm{mg} / \mathrm{mL}$, sodium nitrite had MIC at 0.25 $\mathrm{mg} / \mathrm{mL}$ and $\mathrm{MBC}$ at $1 \mathrm{mg} / \mathrm{mL}$ while cinnamaldehyde had MIC at $0.125 \mu \mathrm{l} / \mathrm{mL}$ and $\mathrm{MBC}$ at $0.25 \mu \mathrm{l} / \mathrm{mL}$. From this, in comparison between the three additives, cinnamaldehyde had the strongest inhibition and lethal effect at lower concentration compared to sodium nitrite which is next to cinnamaldehyde followed by sodium citrate as the weak with higher concentration.

The MIC and MBC value for sodium citrate increases twice the MIC and MBC value of sodium nitrite and cinnamaldehyde. Thus, cinnamaldehyde and sodium nitrite have strong bactericidal and bacteriostatic effect while sodium nitrite has weak bacteriostatic and bactericidal effect. This finding is in agreement with the work of [24]. The MICs of sodium citrate and cinnamaldehyde against $S$. aureus at $5 \mathrm{mg} / \mathrm{mL}$ and $0.5 \mu \mathrm{l} / \mathrm{mL}$ and MBC at $40 \mathrm{mg} / \mathrm{mL}$ and $2 \mu \mathrm{l} / \mathrm{mL}$ respectively. The effect of cinnamaldehyde in fruit juice was reported to be at 0.25 to 1.5 $\mathrm{\mu l} / \mathrm{mL}$ concentration which completely inhibited growth of $S$. enterica and E. coli $\mathrm{O} 157: \mathrm{H} 7$ with MIC value of $0.25 \mu \mathrm{l} / \mathrm{mL}$ [25]

Inhibitory effect of sodium citrate, sodium nitrite and cinnamaldehyde against 24-168hrs $E$. coli $0157: \mathrm{H} 7$ biofilm at $10^{\circ} \mathrm{C}$ and $37^{\circ} \mathrm{C}$

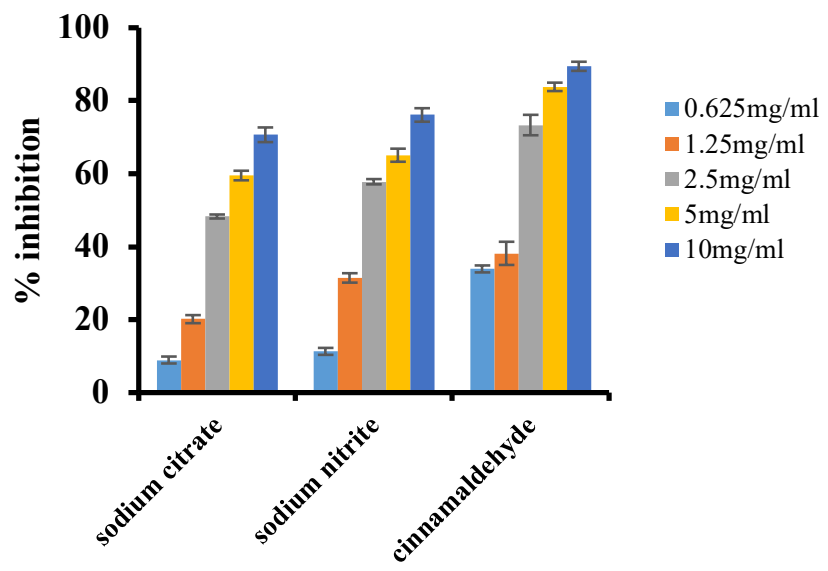

Fig. 2. Percentage (\%) inhibition rate trend of sodium citrate, sodium nitrite and cinnamaldehyde on E. coli $\mathrm{O} 157: \mathrm{H} 7$ biofilm at $10^{\circ} \mathrm{C}$ for $24 \mathrm{hr}$

The bactericidal effect of the various food additives (at different sub-MICs) at $10{ }^{\circ} \mathrm{C}$ and $37{ }^{\circ} \mathrm{C}$ temperatures produced varied results. At $10{ }^{\circ} \mathrm{C}$, sodium citrate (Fig. 2) inhibits biofilm formation of $E$. coli $\mathrm{O} 157: \mathrm{H} 7$ where $0.625-5 \mathrm{mg} / \mathrm{mL}$ exhibited range of $8.9 \%-59.5 \%$ biofilm inhibition. As the concentration increases to $10 \mathrm{mg} / \mathrm{mL}$, more-than $70 \%$ inhibition was observed. Sodium nitrite showed percentage inhibition range of $11.3 \%$ $57.8 \%$ at concentration of $0.625-0.25 \mathrm{mg} / \mathrm{mL}$, as the concentration increases to $0.5-1 \mathrm{mg} / \mathrm{mL}$, percentage inhibition increases from $66.2 \%-70.1 \%$. cinnamaldehyde showed higher percentage inhibition rate of $36.4 \%-60.4 \%$ at $0.625-0.125$ $\mu \mathrm{l} / \mathrm{mL}$, from $0.25 \mu \mathrm{l} / \mathrm{mL}-1.0 \mu \mathrm{l} / \mathrm{mL}$ it inhibited growth of $E$. coli O157:H7 with $70.1 \%-88.9 \%$. cinnamaldehyde exhibit stronger inhibition of E. coli $\mathrm{O} 157: \mathrm{H} 7$ biofilm in comparison with sodium citrate and sodium nitrite. This finding is in agreement with the work of [10] who also reported stronger inhibition potential of cinnamaldehyde against E. coli $\mathrm{O} 157: \mathrm{H} 7$ in carrot juice held at $4^{\circ} \mathrm{C}$ and $12^{\circ} \mathrm{C}$. 


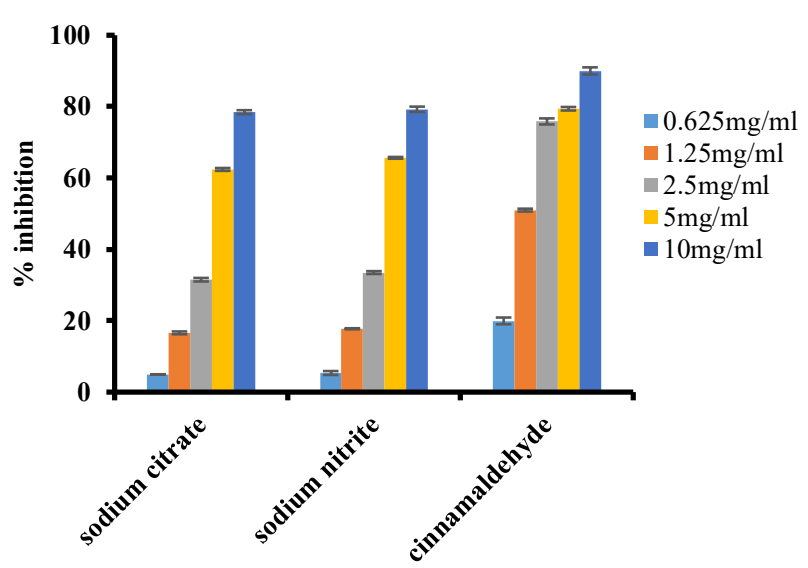

Fig. 3. Percentage (\%) inhibition rate trend of sodium citrate, sodium nitrite and cinnamaldehyde on E. coli $\mathrm{O} 157: \mathrm{H} 7$ biofilm at $37^{\circ} \mathrm{C}$ for $24 \mathrm{~h}$.

Antibiofilm effect of food additive held at $37^{\circ} \mathrm{C}$ also showed a varying effect on $E$. coli $\mathrm{O} 157: \mathrm{H} 7$. Sodium citrate showed (Fig. 3 ) percentage biofilm inhibition of $4.5 \%-31.5 \%$ at $0.625 \mathrm{mg} / \mathrm{mL}$ $-2.5 \mathrm{mg} / \mathrm{mL}$ incubated at $37^{\circ} \mathrm{C}$. At $5 \mathrm{mg} / \mathrm{mL}-10 \mathrm{mg} / \mathrm{mL}$, the percentage inhibition increases from $62.8 \%-78.5 \%$. This finding is not in agreement with the work of [21] who reported higher percentage of biofilm inhibition by sodium citrate. The variation in result may be due to difference in concentration of sodium citrate used in the analysis. Sodium nitrite showed percentage inhibition range of $5.9 \%-33.5 \%$ at concentration of $0.625-0.25$ $\mathrm{mg} / \mathrm{mL}$, as the concentration increases to $0.5-1 \mathrm{mg} / \mathrm{mL}$, percentage inhibition increases from $65.7 \%-79.3 \%$. This shows that sodium nitrite is strong antibiofilm agent when compared to sodium citrate.

Similarly, cinnamaldehyde showed higher percentage inhibition rate of $19.9 \%-51.0 \%$ at $0.625 \mu-0.125 \mu \mathrm{l} / \mathrm{mL}$, from $0.25 \mu \mathrm{l} / \mathrm{mL}-1.0 \mu \mathrm{l} / \mathrm{mL}$ it inhibited growth of $E$. coli $\mathrm{O} 157: \mathrm{H} 7$ with $75.8 \%-90.1 \%$. The comparative analysis showed that cinnamaldehyde is a stronger antibiofilm agent of all the three additives. This finding is in agreement with the work of [24] who reported that cinnamaldehyde has strong antibiofilm effect against Acinetobacter baumannii but contradicts the work of [15] who reported that the inhibition capability of sodium citrate was stronger than cinnamaldehyde. Thus, concluding that sodium citrate, sodium nitrite and cinnamaldehyde have biofilm inhibition effect (antibiofilm).

\section{CONCLUSION}

The isolate was identified to be E. coli $\mathrm{O} 157: \mathrm{H} 7$ through biochemical characterization and latex agglutination test. The antimicrobial susceptibility test conducted revealed that the isolate is susceptible to the additives with showing cinnamaldehyde stronger antimicrobial effect against $E$. coli O157:H7. The minimum inhibitory concentration of sodium citrate required to inhibit the growth of E. coli $\mathrm{O} 157: \mathrm{H} 7$ was obtained at $2.5 \mathrm{mg} / \mathrm{mL}$, sodium nitrite at $0.25 \mathrm{mg} / \mathrm{mL}$ and cinnamaldehyde at $0.125 \mu \mathrm{l} / \mathrm{mL}$. the minimum bactericidal concentration was obtained at $5 \mathrm{mg} / \mathrm{mL}, 1 \mathrm{mg} / \mathrm{mL}$ and $0.25 \mu \mathrm{l} / \mathrm{mL}$ respectively. Biofilm formation potential revealed that the isolate as the ability to form biofilm at $10^{\circ} \mathrm{C}$ and $37^{\circ} \mathrm{C}$ for $168 \mathrm{~h}$ (which was validated by the Congo red method) with variation in number of viable cells. Antibiofilm test exhibited by food additives showed that both sodium citrate (70-78.4\%), sodium nitrite (70$80 \%)$ and cinnamaldehyde $(70-90.1 \%)$ have biofilm inhibition potential (at $10{ }^{\circ} \mathrm{C}$ and $37^{\circ} \mathrm{C}$ ) with strong effect exhibited by cinnamaldehyde. From this finding and comparative analysis, it is concluded that food additives (sodium citrate, sodium nitrite and cinnamaldehyde) have the ability to inhibit and can be used to control biofilm formation of $E$. coli $\mathrm{O} 257: \mathrm{H} 7$.

\section{REFERENCE}

1. Addis M, Sisay D. A review on major food borne bacterial illnesses. J Trop Med Hyg. 2015 3(1); 1000176

2. Theresa A, Boakye YD, Agyare C. Antimicrobial activities and time-kill kinetics of extracts of selected Ghanaian mushrooms. Evid-Based Compl Alt. 2017 Jan 1;2017.

3. Mizan MFR, Jahid, I. K., \& Ha, S. D. (2015). Microbial biofilms in seafood: a food-hygiene challenge. Food Microbiol 49, 41-55.

4. Bean NH, Goulding JS, Lao C, Angulo FJ. Surveillance for foodborne-disease outbreaks--United States, 1988-1992. CDC surveillance summaries: Mmwr-Morbid Mortal W . CDC Surveillance Summaries. 1996: 45(5), 1-66.

5. Kaper JB, Nataro JP, Mobley HL. Pathogenic Escherichia coli. Nat Rev Microbiol. 2004:2(2), 123.

6. Helander IM, Alakomi HL, Latva-Kala K, Mattila-Sandholm T, Pol I, Smid EJ, Gorris LG, Wright AV. Characterization of the action of selected essential oil components on gram-negative bacteria. J Agr Food Chem. 1998:46, 3590-3595.

7. Teodosio J, Simoes M, Mergulhao F. Platforms for invitro biofilm studies. In: Simoes M, Mergulhao F, eds. Biofilms in bioengineering. New York: Nova Science Publishers. 2013.

8. Khribch J, Smara N, Laghrib F, Nassik S, Zrira S, El Houadf M, Oukessou M. Antibacterial activity of cinnamon essential oil (cinnamomum cassia) and cinnamaldehyde on avian Escherichia coli strains Int. J. Agric. Environ. Bio-Res.. 2018: 2:3(4).

9. Adeleke SI. Food poisoning due to yam flour consumption in Kano (Northwest) Nigeria.. 2 Online J. Health Allied Sci. 007:8, 10.

10. Adams TB, Cohen SM, Doull J, Feron VJ, Goodman JI, Marnett LJ, Munro IC, Portoghese PS, Smith RL, Waddell WJ, Wagner BM. The FEMA GRAS assessment of cinnamyl derivatives used as flavor ingredients.Food Chem Toxicol..2004 Feb 1;42(2):157-85.

11. Cucarella C, Solano C, Valle J, Amorena B, Lasa Í, Penadés JR. Bap, a Staphylococcus aureus surface protein involved in biofilm formation. J bacteriol. 2001 May 1;183(9):2888-96.

12. Vasudevan P, Nair MK, Annamalai T, Venkitanarayanan KS Phenotypic and genotypic characterization of bovine mastitis isolates of Staphylococcus aureus for biofilm formation. Vet microbiol. 2003 Mar 20;92(1-2):179-85.

13. Oliveira A, Maria de Lourdes RS. Comparison of methods for the detection of biofilm production in coagulase-negative staphylococci. BMC research notes. 2010 Dec;3(1):1-8.

14. Ejiofor AC, Achi OK, Nwachukwu E, Obeta M, Obiora E, Maduka K, Oraekeyi M, Nkiruka P, and Lote-Nwaru IE. Time Kill Kinetics Study of Commonly Used Disinfectants against Biofilm forming Pseudomonas aeruginosa in Federal Medical Centre, UmuahiaNigeria. Am J Biomed Sci Res. 2020, May: 001155.

15. Habiba U, Rahman MM, Hossain MK, Nur IT. Microbiological profiling of food additives and evaluation of their antibacterial efficacy. Stamford J Microbiol. 2019;9(1):23-6.

16. Khribch J, Smara N, Laghrib F, Nassik S, Zrira S, El Houadf M, Oukessou M. Antibacterial activity of cinnamon essential oil (cinnamomum cassia) and cinnamaldehyde on avian Escherichia coli strains. Int J Agri Environ Biores. 2018: 2:3(4).

17. Liu L, Ye C, Soteyome T, Zhao X, Xia J, Xu W, Mao Y, Peng R, Chen J, Xu Z, Shirtliff ME. Inhibitory effects of two types of food additives on biofilm formation by foodborne pathogens. Microbiol Open. 2019 Sep; 8(9):e00853.

18. Manu DK. Antimicrobial activity of cinnamaldehyde or geraniol alone or combined with high pressure processing to destroy Escherichia coli O157: H7 and Salmonella enterica in juices (Doctoral dissertation, Iowa State University).

19. Merode AE, van der Mei HC, Busscher HJ, Krom BP. Influence of culture heterogeneity in cell surface charge on adhesion and biofilm 
formation by Enterococcus faecalis. J bacteriol. $2006 \mathrm{Apr}$ 1;188(7):2421-6.

20. Mohamed SH, Salem D, Azmy M, Fam NS. Antibacterial and antibiofilm activity of cinnamaldehyde against carbapenemresistant Acinetobacter baumannii in Egypt: In vitro study. J Appl Pharm Sci. 2018 Nov;8(11):151-6.

21. Muazu A, Rahman NI, Aliyu S, Abdullahi UF, Umar AF, Ogidi JA. Differential biofilm formation and chemical disinfection resistance of Escherichia coli on stainless steel and polystyrene tissue culture plate. Int J Res Med Sci. 2015 Nov;3(11):3300-7.

22. Oliveira A, Maria de Lourdes RS. Comparison of methods for the detection of biofilm production in coagulase-negative staphylococci. BMC research notes. 2010 Dec;3(1):1-8.

23. Ter Kuile BH, Kraupner N, Brul S. The risk of low concentrations of antibiotics in agriculture for resistance in human health care. FEMS Microbiol Lett. 2016 Oct 1;363(19).

24. Theresa A, Boakye YD, Agyare C. Antimicrobial activities and time-kill kinetics of extracts of selected Ghanaian mushrooms. Evid-Based Compl Alt. 2017 Jan 1;2017.

25. World Health Organization. Foodborne disease outbreaks: guidelines for investigation and control. World Health Organization; 2008.

26. World Health Organization. Global tuberculosis control: epidemiology, strategy, financing: WHO report 2009. World Health Organization; 2009.

27. World Health Organization. Major foodborne illnesses and causes. Fact Sheet on Food Safety 31st October, 2017. World Health Organisation 2017.

28. Zhang S, Wu Q, Zhang J, Lai Z, Zhu X. Prevalence, genetic diversity, and antibiotic resistance of enterotoxigenic Escherichia coli in retail ready-to-eat foods in China. Food Control. 2016 Oct $1 ; 68: 236-43$. 